\title{
High Prevalence Anemia in Female Adolescents with Low Intake of Vitamins and Minerals
}

\author{
Ani Noviani ${ }^{1}$ \\ Clinical Nutrition, Department of Nutritional Science, \\ Universitas Sebelas Maret \\ Department of Nutrition, Politeknik Kesehatan \\ Tanjungkarang \\ Surakarta, Indonesia \\ aninoviani1411@gmail.com
}

\author{
Dono Indarto ${ }^{2}$ \\ Department of Physiology, Medical Faculty of Universitas \\ Sebelas Maret \\ Post Graduate Program of Nutrition Science, Universitas \\ Sebelas Maret \\ J1. Ir. Sutami No. 36A Surakarta 57126 Indonesia \\ donoind323@gmail.com
}

\author{
Ari Probandari ${ }^{3}$ \\ Department of Public Health \\ Medical Faculty of Universitas Sebelas Maret \\ Jl. Ir. Sutami No. 36A Surakarta 57126 Indonesia \\ ari.probandari@staff.uns.ac.id
}

\begin{abstract}
Anemia is a global public health problem which female adolescents are one of the most vulnerable age groups. Anemia in female adolescents which is caused by micronutrients deficiency can influence physical growth and academic performance. Vitamin and mineral have important roles in erythrocyte formation and enhancement of iron absorption. Hence the objective of this study was to determine association between intake of vitamins, minerals and anemia in female adolescents. This study was conducted in 3 Senior and 2 Vocational High Schools in Sukoharjo Regency, Central Java. There were 120 female adolescents who participated in this study, aged 13-17 years old, and were at year X and XI. They did not have menstruation and worm infection. Anemia was determined from $\mathrm{Hb}$ concentration using the cyanmethemoglobin method while vitamins and minerals intake were obtained from 24-hour recall questionnaire in two alternating days. Association between vitamins and minerals intake and anemia was analyzed using chi-square test $(\mathbf{p}<0.05)$. Anemia was found in $37.5 \%$ female adolescents and the result of chi-square analysis indicated a positive association between folic acid $(\mathrm{OR}=1.6)$, Magnesium $(\mathrm{OR}=1.17)$ and Manganese $(\mathrm{OR}=1.97)$ and anemia, but it was not significant. Inadequate vitamin $B_{12}$ intake increased 1.78 times anemia risk. Higher risk of anemia was found in female adolescents with inadequate intake of Vitamin $B_{1}(O R=1.65)$ and Magnesium $(O R=1.11)$. Whereas adequate intake of Manganese decreased 0.537 times anemia risk. Vitamins and minerals intake do not associate with anemia but it increases anemia risk in female adolescents in Sukoharjo Regency.
\end{abstract}

Keywords - anemia; female adolescents ; vitamin; mineral

\section{INTRODUCTION}

Adolescents which are defined as young people who age 10-19 years old [1,2] are in the transition between childhood and adulthood periods. They critically undergo physical, intellectual, emotional and psychological and behavioural developments [3-5]. Female adolescents are one of the most vulnerable age groups to suffer anemia.

Anemia is an important indicator of poor nutrition and health in many countries in the world [6]. In 2011, $29 \%$ of non-pregnant women and $38.2 \%$ of pregnant women who age 15-49 years have anemia, and the highest prevalence is found in South Asia and Central and West Africa [7]. In Indonesia, anemia is reported in $22.4 \%$ of reproductive women in urban areas and $23 \%$ in rural areas, while anemia in pregnant women is $36.4 \%$ and $37.8 \%$ in the urban and rural areas respectively [8].

Anemia in female adolescents also becomes a global health problem which results in stunted growth, reduced immunity, increased infection rate, delayed menarche and irregular menstruation [4]. In addition, anemia affects brain functions, like reduced concentration and learning and impaired cognitive capacity [9]. Female adolescents have double burden problems if they get pregnant and have anemia, which lead to retardation of their growth and foetal growth, increase of maternal mortality, delivering low birth weight babies and increase of foetal mortality [10].

Iron intake is the most common cause of anemia in all age groups over the world but inadequate intake of other micronutrients is frequently found in female adolescents with anemia. Lack of at least one micronutrient intake will consequently reduce hemoglobin biosynthesis [11]. Low dietary intake of water-soluble vitamins also increases anemia risk. Vitamin $\mathrm{C}$ for example can enhance absorption of iron from vegetables through activation of ferric reductase enzyme and increasing ferro iron solubility. Meanwhile vitamin $\mathrm{B}\left(\mathrm{B}_{2}\right.$, $\mathrm{B}_{6}$, folic acid and $\mathrm{B}_{12}$ ) plays some important roles in erythropoiesis, iron mobilization, globin production and DNA synthesis [12]. 
Mineral deficiencies also lead to anemia with the same mechanism as vitamins do. Inadequate dietary intake of Magnesium (Mg) can disrupt erythrocyte membrane, which become more fragile [13]. In contrast, high intake of Manganese $(\mathrm{Mn})$ will inhibit iron absorption due to their similarity in metal transporter and transport mechanism. As a result, Manganese intake may aggravate anemia status in individual with iron deficiency $[14,15,16]$. The aim of this study was to determine association between intake of vitamins $\mathrm{B}\left(\mathrm{B}_{1}, \mathrm{~B}_{2}, \mathrm{~B}_{6}, \mathrm{~B}_{12}\right.$ and folic acid) and minerals ( $\mathrm{Mg}$ and $\left.\mathrm{Mn}\right)$ and anemia risk in female adolescents.

\section{METHODS}

This cross-sectional study was conducted in 120 female students in year X and XI from three senior and two vocational high schools in four districts in Sukoharjo Regency, Central Java from July to August 2017. Research subjects were selected using multi-stage random sampling. The students were eligible to this study if they aged 13-17 years old and did not have menstruation and worm infection. Approval of this study was obtained from The Ethics Committee in Health Research of Dr. Moewardi General Hospital/School of Medicine, Universitas Sebelas Maret Surakarta with number 483/V/HREC/2017.

Anthropometric data were performed to obtain the nutritional status of female adolescents (BMI for age or zscore), according to WHO Child Growth Standard [www.who.int/childgrowth/en/]. All subjects were interviewed to collect data of food intake using the 24-hour recall method for two alternating days. Collected data were then converted into nutrient daily intake with Nutrisurvey software [http://www.nutrisurvey.de] and compared to the values in Indonesian RDA. Anemia status was assessed using hemoglobin levels with the cyanmethemoglobin method.

Characteristics of research subjects were presented as frequency and percentage. Chi-square and multiple regression logistic tests were performed to analyse the association of vitamin $\mathrm{B}$ and mineral intake and anemia with significance value $<0.05$.

\section{RESULTS}

Table 1 showed basic characteristics of female adolescent who participated in this study. More than a half of subjects $(57.5 \%)$ who aged 16-18 years old and lived in low altitude $(60 \%)$ in Sukoharjo Regency. Six-point seven percent among them had underweight status and $10 \%$ was obesity $(8.3 \%$ overweight and $1.7 \%$ obese). Hemoglobin concentration $<12$ gr\% were observed in $37.5 \%$ female adolescents.
TABLE I

CHARACTERISTICS OF FEMALE ADOLESCENTS OF 3 SENIOR AND 2 VOCATIONAL HIGH SCHOOLS IN SUKOHARJO REGENCY

\begin{tabular}{|l|c|c|}
\hline \multirow{2}{*}{ Characteristics } & \multicolumn{2}{|c|}{ Study participants } \\
\cline { 2 - 3 } & Number & Percentage (\%) \\
\hline Age & & \\
\hline 13 to 15 & 51 & 42.5 \\
\hline 16 to 18 & 69 & 57.5 \\
\hline Geographic & & \\
\hline Low altitude & 72 & 60 \\
\hline High altitude & 48 & 40 \\
\hline Nutritional Status (BMI for age) & & \\
\hline Underweight & 8 & 6.7 \\
\hline Normal & 100 & 83.3 \\
\hline Overweight & 10 & 8.3 \\
\hline Obese & 2 & 1.7 \\
\hline Hemoglobin Concentration & & \\
\hline$<12$ gr\% & 45 & 37.5 \\
\hline$\geq 12$ gr\% & 75 & 62.5 \\
\hline
\end{tabular}

As can be seen from Table II, all female adolescents had lower micronutrient intake compared with RDA except vitamin $\mathrm{B}_{12}$. Mean intake of vitamin $\mathrm{B}_{2}, \mathrm{~B}_{6}, \mathrm{~B}_{12}$ and folic acid in 13-15 years female adolescents was higher than mean intake of vitamin $B_{2}, B_{6}, B_{12}$ and folic acid in 16-18 years female adolescents. While intake of vitamin $\mathrm{B} 1, \mathrm{Mg}$ and $\mathrm{Mn}$ in younger female adolescents was lower than that of older female adolescents. Adequate intake of vitamin $\mathrm{B}_{12}$ was observed in younger female adolescents $(3.42 \pm 5.13 \mathrm{mcg} / \mathrm{day})$ and in older female adolescents $(2.45 \pm 3.50 \mathrm{mcg} / \mathrm{day})$.

TABLE II

MEAN INTAKE OF VITAMINS AND MINERALS IN 120 FEMALE ADOLESCENTS OF 3 SENIOR HIGH SCHOOLS AND 2 VOCATIONAL HIGH SCHOOLS IN SUKOHARJO REGENCY

\begin{tabular}{|c|c|c|c|c|}
\hline \multirow{3}{*}{ Micronutrients } & \multicolumn{4}{|c|}{ Participant age } \\
\hline & \multicolumn{2}{|c|}{ 13-15 years } & \multicolumn{2}{|c|}{$16-18$ years } \\
\hline & RDA & Mean \pm SD & RDA & Mean \pm SD \\
\hline Vitamin $\mathrm{B}_{1}(\mathrm{mg} / \mathrm{d})$ & 1.1 & $0.51 \pm 0.25$ & 1.1 & $0.54 \pm 0.20$ \\
\hline Vitamin $\mathrm{B}_{2}(\mathrm{mg} / \mathrm{d})$ & 1.3 & $0.57 \pm 0.34$ & 1.3 & $0.46 \pm 0.22$ \\
\hline Vitamin $B_{6}(\mathrm{mg} / \mathrm{d})$ & 1.2 & $\begin{array}{c}53.28 \pm \\
46.98\end{array}$ & 1.2 & $\begin{array}{c}45.49 \pm \\
36.76\end{array}$ \\
\hline $\begin{array}{l}\text { Vitamin } \mathrm{B}_{12} \\
(\mathrm{mcg} / \mathrm{d})\end{array}$ & 2.4 & $3.42 \pm 5.13$ & 2.4 & $2.45 \pm 3.50$ \\
\hline Folic acid (mcg/d) & 400 & $\begin{array}{c}105.47 \pm \\
65.09\end{array}$ & 400 & $\begin{array}{c}94.68 \pm \\
54.95\end{array}$ \\
\hline Magnesium (mg/d) & 200 & $\begin{array}{c}139.09 \pm \\
93.78\end{array}$ & 220 & $\begin{array}{c}146.69 \pm \\
67.09\end{array}$ \\
\hline Manganese (mg/d) & 1.6 & $4.91 \pm 7.28$ & 1.6 & $6.15 \pm 5.15$ \\
\hline
\end{tabular}

We further analyzed micronutrient intake which was categorized into adequate and inadequate intake and their association with anemia (Table III). In general, most subjects had inadequate intake of micronutrients in either anemia or non-anemia groups, except vitamin $\mathrm{B}_{12}$ and $\mathrm{Mn}$. We could not statistically analyze vitamin $B_{6}$ intake because all subjects had adequate intake. More anemic female adolescents had inadequate intake of vitamin $\mathrm{B}_{12}(22.5 \%)$ but more non- 
anemic female adolescents had adequate intake of vitamin $\mathrm{B}_{12}$ $(32.5 \%)$. However, it was not statistically significant $(\mathrm{p}=0.203)$. Adequate intake of Mn was mostly found in both anemia and non-anemia groups $(31.7 \%$ and $45.8 \%$ respectively). Inadequate intake of folic acid $(\mathrm{OR}=1.608)$ and $\mathrm{Mg}$ (1.17) was positively associated with anemia, while adequate intake of $\mathrm{Mn}$ was positively associated with anemia $(\mathrm{OR}=1.97)$. However, it was not statistically significant.

TABLE III

ASSOCIATION BETWEEN VITAMINS AND MINERALS INTAKE WITH ANEMIA IN 120 FEMALE ADOLESCENTS OF 3 SENIOR HIGH SCHOOLS AND 2 VOCATIONAL HIGH SCHOOLS IN SUKOHARJO REGENCY

\begin{tabular}{|c|c|c|c|c|c|c|}
\hline \multirow{2}{*}{$\begin{array}{c}\text { Nutrient } \\
\text { Intake }\end{array}$} & \multicolumn{2}{|c|}{ Anemia } & \multicolumn{2}{c|}{ Non-Anemia } & \multirow{2}{*}{ OR } & $\begin{array}{c}\text { p- } \\
\text { value }\end{array}$ \\
\cline { 2 - 5 } Vitamin B1 & & $\%$ & $\mathbf{n}$ & $\mathbf{\%}$ & & \\
\hline Adequate & 3 & 2.5 & 10 & 8.3 & 0.464 & 0.255 \\
\hline Inadequate & 42 & 35 & 65 & 54.2 & & \\
\hline Vitamin $\mathrm{B}_{2}$ & & & & & & \\
\hline Adequate & 3 & 2.5 & 6 & 5 & 0.821 & 1.000 \\
\hline Inadequate & 42 & 35 & 69 & 57.5 & & \\
\hline Folic acid & & & & & & \\
\hline Adequate & 0 & 0 & 1 & 0.8 & 1.608 & 1.000 \\
\hline Inadequate & 45 & 37.5 & 74 & 61.7 & & \\
\hline Vitamin $\mathrm{B}_{12}$ & & & & & & \\
\hline Adequate & 18 & 15.0 & 39 & 32.5 & 0.615 & 0.203 \\
\hline Inadequate & 27 & 22.5 & 36 & 30 & & \\
\hline Magnesium & & & & & & \\
\hline Adequate & 16 & 13.3 & 24 & 20 & 1.172 & 0.689 \\
\hline Inadequate & 29 & 24.2 & 51 & 42.5 & & \\
\hline Manganese & & & & & & \\
\hline Adequate & 38 & 31.7 & 55 & 45.8 & 1.974 & 0.158 \\
\hline Inadequate & 7 & 5.8 & 20 & 16.7 & & \\
\hline
\end{tabular}

In this study, we used multiple logistic regression test to analyze how strong the association between vitamins and minerals intake and anemia. Because age, geographic and $\mathrm{BMI}$ for age also influenced $\mathrm{Hb}$ levels, the multivariate analysis in this study was adjusted with these factors (Table IV). There were only inadequate intake of vitamin $\mathrm{B} 1, \mathrm{~B}_{12}$ and $\mathrm{Mg}$ that increased anemic risk in female adolescents. Female adolescents with inadequate vitamin $\mathrm{B}_{1}$ intake had 1.65 higher risk of anemia than female adolescents with adequate vitamin $\mathrm{B}_{1}$ intake but it was not statistically significant $(\mathrm{p}=0.508)$. The similar trend was also observed in vitamin $B_{12}$ intake. Inadequate intake of vitamin $\mathrm{B}_{12}$ increased 1.78 times risk of anemia in female adolescents. Higher risk of anemia was associated with inadequate intake of $\mathrm{Mg}$, but the anemia risk was lower than inadequate intake of vitamin $\mathrm{B}_{1}$ and $\mathrm{B}_{12}$ $(\mathrm{OR}=1.11,95 \% \mathrm{CI}=0.4642 .655)$. On the other hand, adequate intake of $\mathrm{Mn}$ reduced 0.537 times anemia risk. All variables contributed only $9.5 \%$ in anemia risk of female adolescents.
TABLE IV

RESULT OF MULTIVARIATE ANALYSIS BETWEEN VITAMINS AND MINERALS INTAKE AND ANEMIA ADJUSTED BY AGE, GEOGRAPHIC AND BMI FOR AGE IN 120 FEMALE ADOLESCENTS OF 3 SENIOR HIGH SCHOOLS AND 2 VOCATIONAL HIGH SCHOOLS IN SUKOHARJO REGENCY

\begin{tabular}{|c|c|c|c|c|c|}
\hline & \multirow{2}{*}{ B } & \multirow{2}{*}{$\begin{array}{c}\text { OR Exp } \\
\text { (B) }\end{array}$} & \multicolumn{2}{|c|}{$95 \% \mathrm{CI}$} & \multirow{2}{*}{$\begin{array}{c}p \\
\text { value }\end{array}$} \\
\hline & & & Lower & Upper & \\
\hline $\begin{array}{l}\text { Age }(13-15 \\
\text { years) }\end{array}$ & 0.567 & 1.764 & 0.742 & 4.193 & 0.199 \\
\hline $\begin{array}{l}\text { Geographic } \\
\text { (low altitude) }\end{array}$ & 0.434 & 1.543 & 0.602 & 3.955 & 0.366 \\
\hline $\begin{array}{l}\text { Inadequate } \\
\text { Vitamin } \mathrm{B}_{1} \\
\text { Intake }\end{array}$ & 0.501 & 1.651 & 0.374 & 7.280 & 0.508 \\
\hline $\begin{array}{l}\text { Inadequate } \\
\text { Vitamin } \mathrm{B}_{2} \\
\text { Intake }\end{array}$ & -0.011 & 0.989 & 0.209 & 4.675 & 0.989 \\
\hline $\begin{array}{l}\text { Inadequate } \\
\text { Vitamin } \mathrm{B}_{12} \\
\text { intake }\end{array}$ & 0.576 & 1.780 & 0.765 & 4.142 & 0.181 \\
\hline $\begin{array}{l}\text { Inadequate } \\
\text { Magnesium } \\
\text { intake }\end{array}$ & 0.104 & 1.109 & 0.464 & 2.655 & 0.815 \\
\hline $\begin{array}{l}\text { Adequate } \\
\text { Manganese } \\
\text { intake }\end{array}$ & 0.622 & 0.537 & 0.167 & 1.721 & 0.295 \\
\hline
\end{tabular}

\section{DISCUSSION}

In this recent study, we have documented that the more than a half of female students was in late adolescent period and lived in low altitude within Sukoharjo Regency. Malnutrition was found in $16.7 \%$ female adolescents and $37.5 \%$ female adolescents had anemia. Interestingly, inadequate intake of micronutrients and adequate $\mathrm{Mn}$ intake were common in female adolescents. More anemic female adolescents had inadequate intake of vitamin $\mathrm{B}_{12}$. Besides age and geographic, inadequate intake of vitamin $\mathrm{B} 1$, vitamin $\mathrm{B}_{12}$ and $\mathrm{Mg}$ increased anemia risk in female adolescents. Reduction of anemia risk occurred in female adolescents with Mn adequate intake. All together it suggests that multifactor are involved in anemia in female adolescents.

It is not surprised that late adolescent period and low altitude contribute to anemia risk in our study. Our result is in line with Biradar's (2012) and Kanodia's (2012) studies in Nepal and India which showed that the high prevalence of anemia was in late female adolescents (60 and $45.5 \%$ respectively) [17,18]. However, the main factors underlying anemia in these studies remain unclear.

In normal growth perspective, early and mid-adolescent periods require higher macro and micronutrient intake, compared with late adolescent period. These nutrients are necessarily needed for their physical growth and development $[19,20]$. However, high prevalence of anemia in our study was found in late adolescents. Low altitude probably contributes in female adolescents with anemia because they are more likely to get parasitic, microbial or viral infections during their life, 
compared with female adolescents who lived in high altitude. These microorganisms will use iron from the host body for their metabolism [21]. Unfortunately, we just evaluated worm infection in female adolescents.

High prevalence of anemia in our study is not only related to age and geographic, but also related to low intake of vitamin $\mathrm{B} 1$, vitamin $\mathrm{B}_{12}$ and $\mathrm{Mg}$. However, there is few studies that reported direct association between intake of vitamin $\mathrm{B}_{1}$ and anemia. In general, anemia in female adolescents is commonly caused by low iron intake in their daily diet [22]. However, our findings indicated that vitamin $\mathrm{B}_{12}$ also contributed to anemia in female adolescents. In accordance with our study, two studies have reported that inadequate intake of vitamin $\mathrm{B}_{12}$ is very common in Nepalese and Indian female adolescents, resulting in nutritional anemia [23-24]. For inadequate intake of $\mathrm{Mg}$, our results support the study conducted in Chinese adults that low Mg intake together with low iron intake were increased anemia risk [25]. Mg deficiency can cause anemia because of reduction of hemoglobin synthesis and disruption of cell membrane of erythrocytes [26]. This result support the previous studies that interaction between iron and Mn occurs due to similarities in absorption and transport mechanism. Manganese intake have an important role in iron homeostasis and reduced anemia risk $[27,28]$.

\section{CONCLUSIONS}

High prevalence of anemia was found in female adolescents in Sukoharjo Regency which vitamin B1, B12 and $\mathrm{Mg}$ were the important factors to cause anemia. Nutrition education is required to improve their micronutrient intake to decrease anemia prevalence in female adolescents.

\section{ACKNOWLEDGMENT}

We would like to thank all headmasters of Senior and Vocational High Schools in Sukoharjo Regency for giving permission of this study, Rahanu Clinical Laboratory for blood analysis, enumerators for data collection and my classmate for helping data analysis.

\section{REFERENCES}

[1] WHO. Young people's health - a challenge for society, Report of a WHO Study Group on Young People and "Health for All by the Year 2000". Geneva: World Health Organization, 1986.

[2] WHO. Making health services adolescent friendly Department of Maternal, Newborn, Child and Adolescent Health. Geneva: World Health Organization, 2012.

[3] Steinberg L. Age of opportunity: Lessons from the new science of adolescence. Boston, MA: Houghton Mifflin Harcourt, 2014.

[4] Bindra, V. Anemia in adolescent. World J Anemia. 2017; 1(1): 18-19.

[5] WHO. The health of young people: A challenge and a promise. Geneva: World Health Organization, 1993.

[6] WHO. WHA Global Nutrition Targets 2025: Anemia Policy Brief Geneva: World Health Organization, 2014.

[7] WHO. The global prevalence of anaemia in 2011. Geneva: World Health Organization, 2015.

[8] Ministry of Health Republic of Indonesia. Regulation of Minister of Health Republic of Indonesia No. 75 about Recommended Dietary
Intake for Indonesians. Jakarta: Ministry of Health Republic of Indonesia, 2013.

[9] Gleason, G and Scrimshaw, N.S. Nutritional Anemia: An overview of the functional significance of iron deficiency. Kraemer, K. and Zimmermann M.B. Basel, Switzerland: Sight and Life Press, 2007.

[10] Shipala, E.K, Sowayi, G.A, Kagwiria, M.P, Were, E.O. Prevalence of anemia among teenage pregnant girls attending antenatal clinic in two health facilities in Bungoma District, Western Kenya. J Biol Agric Healthc. 2013; 3 (6): 67-75.

[11] Scott, J.M. Nutritional Anemia: An overview of the functional significance of iron deficiency. Kraemer, K. and Zimmermann M.B. Basel, Switzerland: Sight and Life Press, 2007.

[12] Fishman, M.S., Christian, P. and West Jr, K.P. The role of vitamins in the prevention and control of anaemia. Public Health Nutrition: 2000; 3 (2): $125-150$.

[13] Heaton, F.W., Tongyai, S., Motta, C., Rayssiguier, Y and Guex, E Changes in the erythrocyte membrane during magnesium deficiency. Nutr Res. 1987; 7 (6): 655-663.

[14] Kim, Y., Park., J.K., Choi, Y., Yoo, C.I., Lee, CR., Lee, H., Lee, J.H, Kim, S.R., Jeong, T.H., Yoon, C.S., Park, J.H. Blood manganese concentration is elevated in iron deficiency anemia patients, whereas globus pallidus signal intensity is minimally affected. NeuroToxicology. 2005; 26: 107-111.

[15] Bjørklund, G., Aaseth, J., Skalny, A.V., Suliburska, J., Skalnaya, M.G., Nikonorov, A.A., Tinkov, A.A. Interactions of iron with manganese, zinc, chromium, and selenium as related to prophylaxis and treatment of iron deficiency. J Trace Elem Med Biol. 2017; 41: 41-53.

[16] Kim, Y. and Lee, B.K. Iron deficiency blood manganese level in the Korean general population according to KNHANES 2008 . NeuroToxicology. 2011; 32: 247-254

[17] Biradar, S.S., Biradar, S.P., Alatagi, A.C., Wantamutte, A.S. and Malur, P.R. Prevalence of anaemia among adolescent girls: one-year crosssectional study. J. Clin. Diagn. Res. 2012; 6 (3): 372-377.

[18] Kanodia, P., Bhatta, M., Singh, R.R., Bhatta, N.K. and Shah, G.S. A study of anemia among adolescent girls in eastern of Nepal. JCMS 2016; 12 (1): 19-22.

[19] Özdemir, A. Macronutrients in adolescence. Int. J. Caring Sci. 2016; 9 (2): $1162-1166$

[20] Özdemir, A. Vitamis minerals and fibres in adolescence diet. Int J Caring Sci. 2016; 9 (1): 364-370.

[21] Ganz, T. and Nemeth, E. Iron homeostasis in host defence and inflammation. Nat. Rev. Immunol. 2015; 15 (8): 500-510.

[22] Noviani, A., Indarto, D., Probandari, A. Association among protein and micronutrient intake with anemia incidence of adolescent girls in Sukoharjo, Central Java. In International Conference on Halal Food and Nutrition Sciences, December $16^{\text {th }} 2017$ in Jakarta.

[23] Thomas, D., Chandra, J., Sharma, S., Jain, A. and Pemde, H.K. Determinants of nutritional anemia in adolescents. Indian Pediatrics. 2015; 52: 867-869.

[24] Chandyo, R.K., Ulak, M., Sommerfelt, H., Schneede, J., Ueland, P.M., Strand, T.A. Nutritional Intake and Status of Cobalamin and Folate among Non-Pregnant Women of Reproductive Age in Bhaktapur, Nepal. Nutrients. 2016; 8 (375): 1-14.

[25] Shi, Z., Hu, X., He, K., Yuan, B. and Garg, M. Joint association of magnesium and iron intake with anemia among Chinese adults. Nutrition. 2008; 24: 977-984.

[26] Cosens, G., Diamond, I., Theriault, L.L. and Hurley, L.S. Magnesium deficiency anemia in the rat fetus. Pediat. Res. 1977; 11: 758-764.

[27] Bjørklund, G., Aaseth, J., Skalny, A.V., Suliburska, J., Skalnaya, M.G., Nikonorov, A.A. and Tinkov, A.A. Interactions of iron with manganese, zinc, chromium, and selenium as related to prophylaxis and treatment of iron deficiency. J. Trace Elem. Med. Biol. 2017; 41: 41-53.

[28] Roth, J.A. and Garrick, M.D., Iron interactions and other biological reactions mediating the physiological and toxic actions of manganese. Biochem. Pharmacol. 2003; 66: 1-13. 